\title{
Specificities of protein-protein and protein-DNA interaction of GABP $\alpha$ and two newly defined ets-related proteins
}

\author{
Thomas A. Brown and Steven L. McKnight ${ }^{1}$ \\ Howard Hughes Research Laboratories, Carnegie Institution of Washington, Department of Embryology, \\ Baltimore, Maryland 21210 USA
}

The ets-related protein GABP $\alpha$ interacts with the four ankyrin-type (ANK) repeats of GABP $\beta$ to form a high-affinity DNA-binding complex that recognizes a site important for herpes simplex virus type I immediate early gene activation. To investigate the selectivity and specificity of the GABP complex, we have isolated two new ETS family members, termed ER81 and ER71. ER81 and GABP $\alpha$ were present in most tissues of adult mice, whereas ER71 was restricted to testis. We have compared the DNA-binding specificities of these proteins by binding site selection. GABPa, ER71, and ER81 recognized the common pentanucleotide DNA sequence 5'-CGGAA/T-3'. Although subtle differences were observed for nucleotide preferences flanking this pentanucleotide core, the overall similarity of the selected sequences was most striking. Given the observation that GABP $\alpha$ interaction with GABPB requires its intact ETS domain, we further compared the ability of GABP $\beta$ to interact with other ETS proteins. GABP $\beta$ did not augment the DNA-binding activity of the highly similar ETS domains of ER81, ER71, or Ets-1. Moreover, probing of total tissue extracts with radiolabeled GABP $\beta$ demonstrated its exceedingly stringent specificity for GABP $\alpha$. Given that the DNA-binding specificities of these ETS proteins are similar and that the protein-protein interactions between GABP $\beta$ and GABP $\alpha$ are highly specific, we conclude that the protein interactions determine the target site selection by GABPa.

[Key Words: ETS domain; transcription factor; Notch; ets; DNA-binding protein; testis; ankyrin repeats]

Received September 22, 1992; revised version accepted October 22, 1992.

The heteromeric DNA-binding complex termed GABP was isolated previously on the basis of its ability to bind to a cis-regulatory DNA sequence important for herpes simplex virus type 1 (HSV-1) immediate early (IE) gene activation (Triezenberg et al. 1988; LaMarco and McKnight 1989; LaMarco et al. 1991). Characterization of GABP revealed that two distinct subunits, GABP $\alpha$ and GABP $\beta$, associate to form an $\alpha_{2} \beta_{2}$ tetramer (Thompson et al. 1991). Subunit association was shown to increase the affinity of binding to two directly repeated GA-rich cis-regulatory elements present in the promoters of HSV-1 IE genes. Four 32- to 33-amino-acid ankyrin-type (ANK) repeats, similar to those found in a wide variety of cellular proteins (Michaely and Bennett 1992), mediate the ability of GABP $\beta$ to interact with GABP $\alpha$ (Thompson et al. 1991|. The portion of GABP $\alpha$ sufficient for subunit association includes an ETS domain (Thompson et al. 1991).

Members of the ETS family of DNA-binding proteins contain an $\sim 85$-amino-acid region of similarity called the ETS domain (Karim et al. 1990). This domain, char-

'Present address: Tularik, Inc., South San Francisco, California 94080 USA. acterized by a hydrophobic region containing 3 tryptophan residues spaced 17-18 residues apart, followed by a segment rich in basic amino acids, is sufficient for sequence-specific binding to DNA at a purine-rich core sequence, GGAA/T (Klemsz et al. 1990; Thompson et al. 1991; Nye et al. 1992). In several cases, including Ets-1, PEA3, SAP-1, and PU.1, these proteins have been shown to function as transcriptional activators (Klemsz et al. 1990; Wasylyk et al. 1991; Dalton and Treisman 1992; Xin et al. 1992).

ETS family members have been implicated in a variety of biologically important processes. Ets-1 was originally identified as the progenitor of v-ets, a portion of an oncogene associated with transformation of erythroblasts by avian retrovirus E26 (Leprince et al. 1983; Nunn et al. 1983). Since that time, PU.1/Spi-1 and Fli-1 have also been implicated in the induction of erythroleukemia (Moreau-Gachelin et al. 1988, Goebl 1990; Klemsz et al. 1990; Ben-David et al. 1991). Other ETS proteins have been isolated by virtue of their ability to bind to viral gene promoters. PEA3, for example, binds to polyoma virus enhancer (Xin et al. 1992), GABP binds to HSV-1 IE gene promoters (LaMarco et al. 1991), and a GABP-related factor binds to adenovirus promoters (Watanaba et 
al. 1990). It is now apparent that many members of this family exist in multicellular organisms, including ets-1, ets-2, erg, elk-1, PU.1, E74, Fli-1, elf-1, SAP-1, PEA-3, and $\mathrm{GABP} \alpha$ (see Fig. 2, below, and references therein). Given that each of these proteins appears to bind similar DNA sequences, the question arises as to how these factors might undertake biologically distinct functions. As part of our efforts in understanding the action of GABP and other ETS family members, we have isolated two new members of this gene family, termed ER71 and ER81. We have compared their tissue distribution, DNA-binding specificity, and ability to interact with GABP $\beta$. The results of our studies dramatically emphasize the importance of protein-protein interaction in the functional specificity of ETS proteins.

\section{Results}

Isolation of the ets-related genes ER71 and ER81

An 8.5-day mouse embryo cDNA library was screened using degenerate oligonucleotides designed to recognize two conserved regions within the DNA-binding domain of ets-related proteins (see Materials and methods). Two different cDNA clones, termed ets-related 71 (ER71) and ets-related 81 (ER81), were isolated and sequenced (Fig. 1). The largest ER71 clone obtained was $1066 \mathrm{bp}$ in length. The cDNA contained an open reading frame (ORF) beginning at its $5^{\prime}$ terminus and ending at a stop codon just before a contiguous segment of adenine residues. The amino acid numbering of the ORF begins at the first methionine residue downstream from the $5^{\prime}$ terminus of the cDNA. An in-frame stop codon was not identified upstream of the first methionine residue. Therefore, we cannot be certain that this clone represents the entire coding portion of the mRNA. However, Northern blot analysis showed the embryo mRNA to be $\sim 1.2 \mathrm{~kb}$ in length (Fig. 3, below). Given that the native poly(A) region should add $\sim 100-200$ nucleotides not present in the cDNA, it is likely that this cDNA clone represents a nearly full-length copy of the mRNA expressed in mouse embryos. The encoded ER71 protein is predicted to be 335 amino acids in length corresponding to a molecular mass of 37,047 daltons.

The ER81 cDNA consisted of 2514 nucleotides and contained a single long ORF. The ER81 protein product was predicted to be 477 amino acids corresponding to a molecular mass of 55,040 daltons. Both ER71 and ER81 encode an ETS domain located near their respective carboxyl termini. Sequence comparisons with the ETS domains of other related proteins and percent identity to GABP $\alpha$ are shown in Figure 2. Comparison of this 85 amino-acid region with known proteins present in the GenBank data base revealed that ER71 was most similar in amino acid sequence to ets-1 (68\% identical) and ER81 was most similar to PEA3 (95\% identical). ER71 shared no significant amino acid sequence similarity to other ets-related proteins outside of the ETS domain. ER81 was, however, $54 \%$ identical to murine PEA3 throughout the entire ORF of the protein.

\section{Expression patterns of ER71 and ER81}

The sizes and distributions of the ER81 and ER71 mRNAs were determined by Northern blot analysis of mRNA prepared from various mouse tissues (Fig. 3). ER81 was found in a wide variety of tissues. In most tissues, two mRNA species of $\sim 6.5$ and $\sim 3.2 \mathrm{~kb}$ were observed. These two ER81 mRNAs were most abundant in kidney; moderately abundant in heart, brain, lung, and embryo; low in spleen, intestine, testis, and thymus; and undetectable in liver. In addition, testis contained moderately abundant levels of an $\sim 2.5$-kb ER $81 \mathrm{mRNA}$. This probe did not detect the related PEA3 mRNA under these conditions because the sizes and distribution of ER81 mRNAs are different from those reported for PEA3 (Xin et al. 1992). In the adult mouse, ER71 mRNA was detected only in testis. In testis, the ER71 mRNA was $\sim 1.7 \mathrm{~kb}$, whereas embryos expressed a smaller mRNA of $\sim 1.2 \mathrm{~kb}$.

The identical filter used for analysis of ER81 and ER71 mRNA was also probed for GABP $\alpha$ mRNA (Fig. 3). With several exceptions, Northern blot analysis of GABP $\alpha$ mRNA expression was similar to that published previously (LaMarco et al. 1991). Three predominant species of $\mathrm{GABP} \alpha(\sim 5.0, \sim 2.8$, and $\sim 2.6 \mathrm{~kb})$ were most abundant in preparations of thymus and embryo mRNA yet were also present in a wide variety of tissues. In addition to these previously recognized species, the current analysis revealed an additional $\sim 1.7-\mathrm{kb}$ GABP $\alpha$ mRNA present in spleen, testis, embryo, and thymus. In our previously published report, GABP $\alpha$ was clearly expressed in the brain (LaMarco et al. 1991). However, in two separate experiments we have been unable to detect GABP $\alpha$ mRNA in the brains of 18-month-old mice. The mRNA isolated from these brains was shown in both cases to be intact by two criteria. First, methylene blue staining showed the RNA to be intact (not shown). Moreover, when the identical filter containing the brain mRNA was probed with ER81 cDNA, its corresponding mRNA was clearly detected (see Fig. 3). The absence of detectable GABP $\alpha$ mRNA in RNA samples that clearly contained intact mRNA may be indicative of physiologically important regulation of GABP $\alpha$ in the brain (see Discussion).

\section{Comparison of optimal DNA-binding site for three ETS family members}

Given the widespread expression of GABP $\alpha$ and ER81 mRNA, it is likely that multiple ETS family members are expressed in the same cell at the same time. The question arises, therefore, as to what mechanisms determine the selective targeting of different genes by different ETS family members. One possible explanation is that different ets-related proteins, despite sharing highly related DNA-binding domains, recognize different DNA sequences. To test this possibility, we used the polymerase chain reaction (PCR)-based binding site selection method of Blackwell and Weintraub (1990) to compare 
ER71

AGAACCGTCAGAACAAGCATCCATGGACCTGTGGAACTGGGATGAGGCGTCACTGCAGGA 60

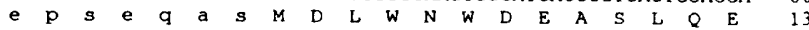
AGTGCCTCCTGGGGACAAGCTGACAGGACTGGGAGCGGATTTGGTTTCTATTTCCCTGA 120

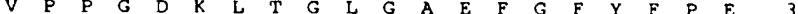
AGTGGCTCTACAAGAGGACACACCGATCACACCAATGAACGTAGAAGGCTGCTGGAAAGG 18 $\begin{array}{llllllllllllllllllllllllll}V & A & L & Q & E & D & T & P & I & T & P & M & N & V & E & G & C & W & K & G & 53\end{array}$ GTTCCCAGAGCTGGACTGGAACCCCGCTTTACCTCACGAAGACGTACCTTTCCAGGCGGA 240

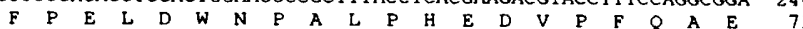
GCCCGTTGCTCACCCCCTTCCGTGGTCGCGAGACTGGACAGACCTGGGATGCAACACCTC 300

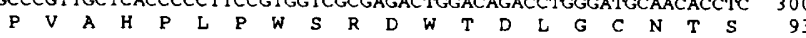
GGACCCGTGGAGCTGTGCTTCACAGACGCCAGGCCCTGCCCCTCCTGGCACGAGCCCCTC 360 $\begin{array}{lllllllllllllllllllll}D & P & W & S & C & A & S & Q & T & P & G & P & A & P & P & G & T & S & P & S & 113\end{array}$ CCCCTTCGTCGGCTTTGAAGGGGCGACCGGCCAGAATCCTGCCACCTCGGCAGGAGGGGT 420 $\begin{array}{llllllllllllllllllllll} & P & F & V & G & F & E & G & A & T & G & Q & N & P & A & T & S & A & G & G & V & 133\end{array}$ CCCCTCGTGGTCGCACCCTCCAGCTGCCTGGAGCACTACCAGCTGGGACTGTTCTGTGGG 480 $\begin{array}{lllllllllllllllllllll}P & S & W & S & H & P & P & A & A & W & S & T & T & S & W & D & C & S & V & G & 153\end{array}$ CCCCAGTGGCGCCACCTACTGGGACAATGGCCTGGGCGGGGAAGCGCATGAGGACTATAA 540 $\begin{array}{lllllllllllllllllllll}P & S & G & A & T & Y & W & D & N & G & \text { L } & G & G & E & A & H & E & D & Y & K & 173\end{array}$ AATGTCATGGGGCGGGTCTGCCGGTTCGGACTACACCACCACGTGGAATACTGGGCTGCA 600 $\begin{array}{lllllllllllllllllllll}M & S & W & G & G & S & A & G & S & D & Y & T & T & T & W & N & T & G & L & Q & 193\end{array}$ GGACTGCAGCATCCCTTTCGAGGGGACCAGAGTCCAGCATTCACCACGCCCTCCAAATC 660 $\begin{array}{lllllllllllllllllllll}D & C & S & I & P & F & E & G & H & Q & S & P & A & F & T & T & P & S & K & S & 213\end{array}$ GAACAAGCAGTCTGATAGAGCCACATTGACTCGCTACTCCAAAACTAACCACCGAGGTCC 720 $\begin{array}{lllllllllllllllllllllllll}N & K & Q & S & D & R & A & T & L & T & R & Y & S & K & T & N & H & R & G & P & 233\end{array}$ CATTCAGCTGTGGCAATTCCTCCTGGAGCTGCTCCAAGACGGGGCTCGCAGCAGCTGCAT 780 $\begin{array}{lllllllllllllllllllll}I & O & L & W & O & F & L & L & E & L & L & O & D & G & A & R & S & S & C & I & 253\end{array}$ CCGCTGGACGGGCAATAGCCGCGAGTTCCAGCTGTGCGACCCCAAAGAGGTGGCCCGGCT 840 $\begin{array}{llllllllllllllllllllll}R & \text { W } & \text { T } & G & \text { N } & \text { S } & \text { R } & \text { E } & \text { F } & \text { Q } & \text { L } & \text { C } & \text { D } & \text { P } & \text { K } & \text { E } & \text { V } & \text { A } & \text { R } & \text { L } & 273\end{array}$ GTGGGGCGAGCGCAAGAGGAAGCCGGGAATGAATTATGAGAAACTGAGTCGAGGTCTACG 900

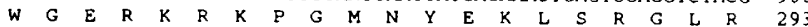
TTATTATTACCGCCGCGACATCGTGCTCAAGAGTGGTGGGCGCAAGTACACATACCGCTT 960

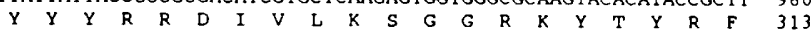
CGGGGGACGTGTGCCTGTCCTCGCCTATCAGGATGATATGGGGCATCTGCCAGGTGCAGA 1020

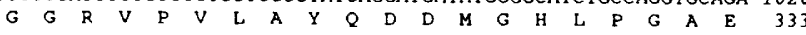
AGGCCAATAAAACAAAAAACAAAAACAAAAAAAAAAAAAAAAAAAA G Q

Figure 1. Nucleotide and deduced amino acid sequences of ER71 (left) and ER81 (right). The deduced amino acid sequences are shown in single-letter code beneath the corresponding codons of the nucleotide sequence. Nucleotide and amino acid numbers are shown at the right. The lowercase letters in ER71 depict amino acid sequence corresponding to the predicted ORF before the first methionine residue in the cDNA.

the optimal binding sites for GABP $\alpha, E R 71$, and ER81 (Fig. 4). Polypeptides containing the entire ETS domain of $\mathrm{GABP} \alpha$, ER71, and ER81 were used to select binding
ER81

CAGCTCTGTCAGAGGCGCTTTCGGCTTCCAAGGGGAAGTGCTGGGCAATAATTAATGTTT 60 TTATTAAATTTGGAGGGAATTTTTTGCAGCCGTTCGCCTAGCGTGGCCTTCAGGTTGATA 120 GAAGTCCAGATCCCGAGGAAATCTCCAGCTAAATGCTCAAAATATAAAACACTGAGCTAA 180 TATTTGCGAAGAGGAGCAGAATGGATGGATTTTATGACCAGCAAGTGCCTTACGTGGTCA 240 $\begin{array}{lllllllllllllll}M & D & G & F & Y & D & Q & Q & V & P & Y & V & V & T & 14\end{array}$

CCAACAGTCAGCGTGGGAGAAACTGTACCGAGAAACCAACAAATGTCAGGAAAAGAAAAT 300

TCATTAACAGAGATCTGGCTCATGATTCAGAaGAACTCTTTCAAGATCTGAGTCAGTTAC 360

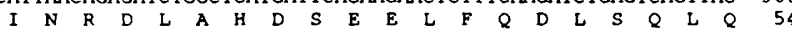

AAGAAACATGGCTTGCTGAAGCTCAGGTACCTGACAATGATGAGCAGTTTGTTCCAGACT 420

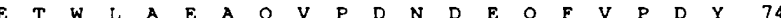

ATCAGGCTGAAAGTTTGGCTTTTCATGGCCTCCCACTGAAAATCAAGAAAGAACCCCACA 480

$\begin{array}{lllllllllllllllllllll}Q & A & E & S & L & A & F & H & G & L & P & L & K & I & K & K & E & P & H & S & 94\end{array}$ GCCCATGTTCAGAACTCGGGTCTGCTTGCAGTCAAGAGCAGCCCTTTAAATTCAGCTATG 540 $\begin{array}{lllllllllllllllllllll}P & C & S & E & L & G & S & A & C & S & Q & E & Q & P & F & K & F & S & Y & G & 114\end{array}$ GAGAAAAGTGCCTGTACAATGTCAGTGCCTATGATCAGAAGCCACAAGTGGGATGAGGC 600 $\begin{array}{llllllllllllllllllllllllll}E & K & C & L & Y & N & V & S & A & Y & D & Q & K & P & Q & V & G & M & R & P & 134\end{array}$ CCTCCAATCCCCCGACACCATCCAGCACTCCAGTGTCCCCACTACACCATGCATCTCCAA 660 $\begin{array}{lllllllllllllllllllllll}S & N & P & P & T & P & S & S & T & P & V & S & P & L & H & H & A & S & P & N & 154\end{array}$ ACACAGCTCATACTCCGAAACCTGACCGGGCCTTCCCAGCTCACCTCCCTCCTTCTCAGT 720 $\begin{array}{llllllllllllllllllllll}T & \text { A } & \text { H } & \text { T } & \text { P } & \text { K } & \text { P } & \text { D } & \text { R } & \text { A } & \text { F } & \text { P } & \text { A } & \text { H } & \text { L } & \text { P } & \text { P } & \text { S } & \text { Q } & \text { S } & 174\end{array}$ CCATACCAGACAGCACCTACCCCATGGACCACAGATTTCGCCGCCAGCTTTCTGAACCCT 780

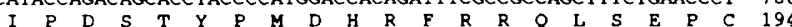
GTAATTCTTTTCCTCCTTTGCCGACAATGCCAAGGGAAGGGCGTCCTATGTACCAACGCC 840 $\begin{array}{lllllllllllllllllllll}N & S & F & P & P & L & P & T & M & P & R & E & G & R & P & M & Y & Q & R & Q & 214\end{array}$ AGATGTCTGAGCCAAACATCCCCTTCCCACCACAAGGCTTTAAGCAGGAGTACCACGACC 900 $\begin{array}{llllllllllllllllllllllllllll}M & S & E & P & N & I & P & F & P & P & Q & G & F & K & Q & E & Y & H & D & P & 234\end{array}$ CAGTCTATGAACATACCACCATGGTTGGCGGTGCAGCCAGCCAAAGCTTCCCCCCTCCTT 960 $\begin{array}{lllllllllllllllllllllllll}V & Y & E & H & T & T & M & V & G & G & A & A & S & Q & S & F & P & P & P & L & 254\end{array}$ TGATGATCAAACAGGAACCCAGAGATTTTGCATATGACTCAGAAGTGCCTAGCTGCCACT 1020

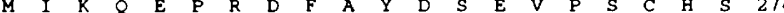
CCATTTATATGAGGCAAGAAGGCTTCCTGGCTCATCCAAGCAGAACAGAAGGCTGCATGT 1080 $\begin{array}{lllllllllllllllllllll}I & Y & M & R & Q & E & G & F & \text { L } & \text { A } & \text { H } & \text { P } & \text { S } & R & \text { T } & \text { E } & \text { G } & \text { C } & \text { M } & \text { F } & 294\end{array}$ TTGAGAAGGGTCCCAGGCAGTTCTATGATGACACCTGTGTGGTCCCGGAGAAGTTCGATG 1140

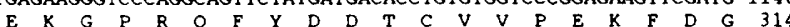
GGGACATTAAGCAAGAGCCTGGAATGTACCGGGAAGGACCCACGTACCAGAGGCGAGGAT 1200 $\begin{array}{lllllllllllllllllllll}D & I & K & Q & E & P & G & M & Y & R & E & G & P & T & Y & Q & R & R & G & S & 334\end{array}$ CCCTCCAGCTCTGGCAGTTTTTGGTAGCTCTTCTGGATGACCCTTCAAATTCTCATITCA 1260 $\begin{array}{lllllllllllllllllllll}\text { L } & Q & L & \text { W } & Q & F & \text { L } & \text { V } & \text { A } & \text { L } & \text { L } & \text { D } & \text { D } & \text { P } & S & \text { N } & S & \text { H } & F & \text { I } & 354\end{array}$ TTGCCTGGACTGGACGAGGCATGGAATTTAAACTGATTGAGCCCGAAGAGGTGGCCCGGC 132 $\begin{array}{lllllllllllllllllllll}A & W & T & G & R & G & M & E & F & K & L & I & E & P & E & E & V & A & R & R & 374\end{array}$ GTTGGGGCATTCAGAAGAACAGGCCGGCGATGAACTATGACAAACTTAGTCGTTCTCTCC 1380 $\begin{array}{llllllllllllllllllllll}\text { W } & G & I & Q & K & N & R & P & A & M & N & Y & D & K & L & S & R & S & L & R & 394\end{array}$ GCTATTATTATGAGAAGGGATCATGCAAAAGGTGGCTGGAGAAAGATACGTGTACAAAT 1440 $\begin{array}{lllllllllllllllllllll}Y & Y & Y & E & K & G & I & M & Q & K & V & A & G & E & R & Y & V & Y & K & F & 414\end{array}$ TTGTGTGTGACCCGGAAGCCCTTTTCTCTATGGCCTTTCCGGATAACCAGCGCCCACTGC 1500 $\begin{array}{lllllllllllllllllllll}V & C & D & P & E & A & L & F & S & M & A & F & P & D & N & Q & R & P & L & L & 434\end{array}$ TGAaGACGGACATGGAACGTCACATCAACGAAGAGGACACAGTGCCTCTGTCTCACTTTG 1560 $\begin{array}{lllllllllllllllllllll}K & T & D & M & E & R & H & I & N & E & E & D & T & V & P & \text { L } & \text { S } & \text { H } & \text { F } & \text { D } & 454\end{array}$ ATGAGAGCATGACCTACATGCCCGAAGGGGCTGCTGCAACCCTCACCCCTACAACGAAG 1620 $\begin{array}{lllllllllllllllllllll}E & S & M & T & Y & M & P & E & G & G & C & C & N & P & H & P & Y & N & E & G & 474\end{array}$ $\begin{array}{lr}\text { GATACGTGTACTAACATGAGTAACCCGTCAAGCAAGGCACCCCGTCGTTCGCCTCTTTTTT } & 1680 \\ Y & 477\end{array}$

477

TTTCAAGATGCAGAGAATCACCGAATTCTCTTCGATGTTTGTTTTATTTCTGTTGTTTG 1740 TACTTTATTTTTTAAATGATAATACAAAAGGGGGCTTTTCCTGTTCCATTATTCTATGGT 1800 CTGCCATGGACTGCGCACTTTATTTGCTGGTGGGCGGGAGTAATCTAGACATTCATTCTT 1860 TGTAACAGGAAGATGGCGGATGAGTGGGCAGAAGGAGCTGAGGGATTCCTTTTTGCTTAG 1920 GCTTGGAATGGAGTCTACAGGTTTTCTGTATGATGATGCTATATCATATTTGTTCGATTT 1980 CATAATAACGTAAGATAATTTTCCTGGGTATCTACGGTACAGTTGATTTCACGTTGTGT 204 AAATATCTTCTTGGAGACCATTTGCCTTGGGCATTTCCCCCATCATTACTGAGTCTCTGC 210 AGGTGTACAAAAATCTACTGTAAATGGCAGTTTAATGTTAGAAATTACTGTTTTGCACCT 2160 CTTGTAAAAAAAAAATATTTAGCAATTGCATTTGTTGTTCTTTCTGTTTCATAATGCTTT 2220 ACAGATGACTTGTAGAGGAAAAACCCTAAATGTGGGCAATTCTCTCTGAAGTTGAGTAAT 228 CACCATGACTGTAAATGCGGGCCACCGTTTTGGACTCTGGCTCCAACTGAGTCACAGGCC 2340 AGTAGCATTTTATGTATCTGGTGCCATCCTGCTGTTITGGTACTACAAATACTGTCTTTT 2400 $\begin{array}{ll}\text { AAATATGTTGATGCCCATCTCAC'TTAAATAATGACATGTCATGATCCTTCGGAATCTTCA } 2460 \\ \text { TTTAAGTGTTAAAGCTGGATCACAATGAAGCAAAAAATAAAAAAAAAAAAAA } & 2514\end{array}$

2514

sites from an oligonucleotide population prepared with 4 random nucleotides flanking both sides of a central GA dinucleotide. Following three iterations of gel-shift and 


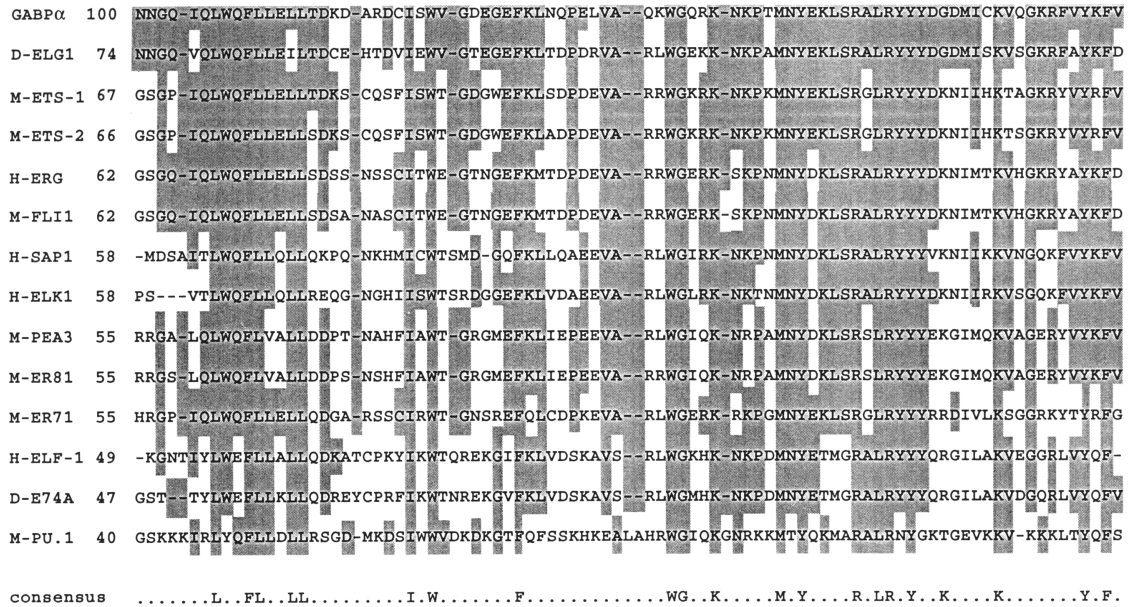

Figure 2. Comparison of the ETS domain of ER71, ER81, and other known ETS gene family members with GABP $\alpha$. Conserved amino acids are shaded, and the percent identity with GABP $\alpha$ is indicated. The consensus sequence is shown at the bottom. Sources of gene family members are as follows: M-GABPa (LaMarco et al. 1991); M-ets-1 (Gunther et al. 1990); M-ets-2 (Watson et al. 1988); H-erg (Reddy et al. 1987); H-elk-1 (Rao et al. 1989); M-PU.1 (Klemsz et al. 1990); D-E74 (Burtis et al. 1990|; M-fli-1 (Ben-David et al. 1991), H-elf-1 (Thompson et al. 1992); H-SAP-1 (Dalton and Triesman 1992); M-PEA-3 (Xin et al. 1992); D-elg-1 (Pribyl et al. 1991; Chen et al. 1992).
PCR amplification, the selected populations were sequenced. For the purpose of discussion we refer to the following system: $5^{\prime}-\mathrm{NNNNGANNNN-3}$ is numbered $-4,-3,-2,-1,0,0,+1,+2,+3,+4$ (see Table 1 ).

The binding sites selected by GABP $\alpha, E R 71$, and ER81 contained the core sequence GGAA/T. Subtle differences in binding specificity were detected at positions outside of this core. The most noticeable difference was that ER71 selected a $C$ residue at position +4 , whereas neither GABP $\alpha$ nor ER81 exhibited any preference at this position. At position $-4, G A B P \alpha$ selected $G$ or $A$ equally, whereas ER81 selected G most strongly with modest selectivity for A. At this same -4 site, ER71 selected a $G$ or $C$ equally. Slight differences were also detected in the the ratio of $C$ versus $G$ at position -3 and the ratio of $\mathrm{A}$ versus $\mathrm{T}$ at position +1 . At position -3 , GABP $\alpha$ favored $C$ over $G$, ER81 favored $G$ over $C$, and ER71 tolerated $G$ or C equally. Finally, GABP $\alpha$ favored A over $T$ at position +1 , whereas ER71 and ER81 tolerated an $\mathrm{A}$ or $\mathrm{T}$ equally.

Perhaps more striking than the slight differences noted in the aforementioned paragraph was the overall similarity of the selected sequences. The sequences selected by these three ets-related proteins were almost identical for
8 nucleotides: SMGGAWRY (DNA degenerate alphabet: $\mathrm{N}=\mathrm{A}, \mathrm{C}, \mathrm{G}$, or $\mathrm{T} ; \mathrm{S}=\mathrm{G}$ or $\mathrm{C} ; \mathrm{R}=\mathrm{A}$ or $\mathrm{G} ; \mathrm{M}=\mathrm{A}$ or $\mathrm{C}$; $\mathrm{W}=\mathrm{A}$ or $\mathrm{T} ; \mathrm{Y}=\mathrm{C}$ or $\mathrm{T}$ ). Their are several reasons to believe that the subtle differences in binding site selectivity may be insufficient to account for selectivity in target gene activation by the members of this family of transcription factors. For example, the GABP-binding site in the promoter of the ICP4 gene (AACGGAAGCGGAAACC) contains two sites that very closely resemble the optimal sequences of these three ets-related proteins. Based on the binding site selection alone, you would expect the second site to be preferentially recognized by ER81 because of the G residue present at position -3 . However, oligonucleotide affinity chromatography of rat tissue extracts resulted in the purification of only GABP and not ER81 or other ETS proteins /LaMarco and McKnight 1989; LaMarco et al. 1991). It would appear, therefore, that selectivity for this site is governed by other determinants, such as post-translational modification or protein-protein interactions. Consistent with this hypothesis, we have demonstrated previously that complex formation of GABP $\alpha$ at the duplicate GA-rich binding sites in the HSV-1 ICP4 gene is dramatically influenced by a second protein termed GABP $\beta$.
$\operatorname{GABP} \alpha$

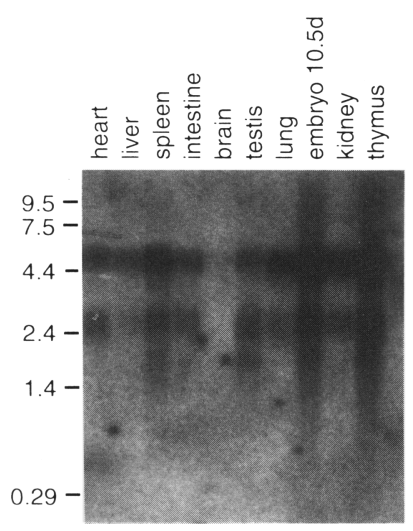

ER81

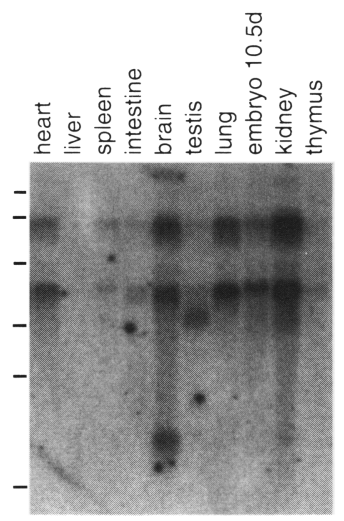

ER71

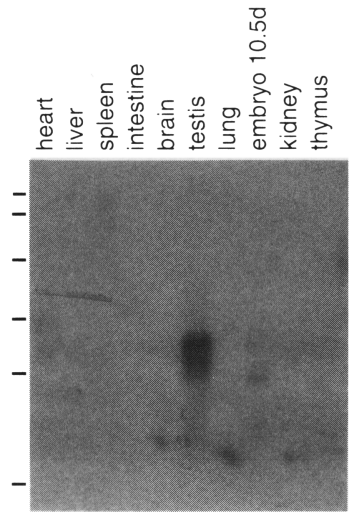

Figure 3. Northern blot analysis of $\mathrm{GABP} \alpha, E R 71$, and ER81 mRNAs from various mouse tissues. Ten micrograms of poly $\mid A)^{+}$RNA was loaded in each lane. Multiple probings of a single filter are represented. The probe used is indicated above each blot, and the tissue source of RNA is indicated above each lane. The positions of RNA standards are indicated at left. 
Figure 4. Nucleotide sequence of the binding site selected by GABP $\alpha$, ER81, and ER71. Autoradiography of DNA sequencing after three rounds of gel-shift and PCR implification by the protein indicated above each panel. The sequence of the starting oligonucleotide is shown in the left panel (Free). The selected nucleotides are designated by letters at the right as the complementary nucleotide determined from the sequencing gel.

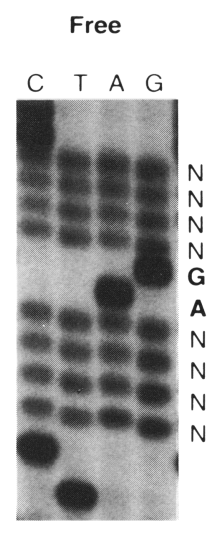

$\operatorname{GABP}(x$
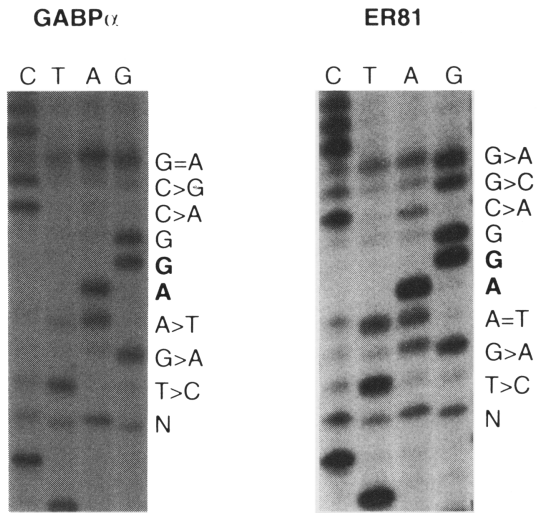

ER71

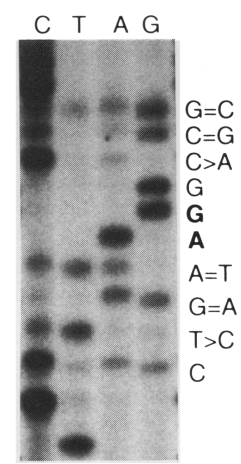

$G A B P \beta$ does not change the specificity of $G A B P \alpha$ binding at a single site

We have demonstrated previously the dramatic quantitative effect of GABPB on the DNA-binding affinity of $\mathrm{GABP} \alpha$. We have also demonstrated that GABP $\beta$ can be cross-linked to DNA by UV irradiation, indicating its close proximity to DNA (Thompson et al. 1991). Here, we have tested whether the proximity of GABP $\beta$ to DNA has a qualitative effect on the DNA-binding specificity of GABP $\alpha$ (Fig. 5). Binding site selection in the presence and absence of GABP $\beta$ revealed that no sequence differences were detected in the populations of oligonucleotides selected by GABP $\alpha$ alone or the GABP $\alpha / G A B P \beta$ complex. Therefore, GABP $\beta$ somehow affects the affinity of DNA interaction without altering the specificity of sequence recognition.

$G A B P \beta$ does not associate with or abet the DNA-binding activity of ER71, ER81, or Ets-1

If the functional selectivity of ets-related proteins is significantly influenced by protein-protein interactions, one might anticipate that such interactions would be highly specific. We have tested the functional specificity of GABP $\beta$ by assessing its ability to interact with several ets-related proteins. Portions of GABP $\alpha, E R 71$, ER81, and Ets-1 containing the ETS domain were expressed in bacteria and purified (see Material and methods). Each of these ets-related proteins was analyzed for its ability to interact with DNA and GABP $\beta$ in a gel-shift assay. All proteins tested, GABP $\alpha, E R 71, E R 81$, and Ets-1, effectively bound an oligonucleotide containing a single CGGAA site (Fig. 6). Upon addition of GABP $\beta$, GABP $\alpha$ was quantitatively shifted to a slower migrating complex. Similarly supershifted complexes were not observed with ER71, ER81, or Ets-1. Given that Ets-1 is more similar to GABP $\alpha$ than any murine ETS family member yet cloned, these observations provide the initial indication that GABP $\beta$ may be dedicated to only one of the ETS family members (Fig. 2).

\section{$G A B P \beta$ is highly specific for $G A B P \alpha$}

Although GABP $\beta$ did not functionally abet the DNAbinding activity of ER71, ER81, or Ets-1, it is possible

Table 1. Nucleotide sequence determined by binding site selection

\begin{tabular}{|c|c|c|c|c|c|c|c|c|c|c|}
\hline & $\begin{array}{r}-4 \\
\mathrm{~N}\end{array}$ & $\begin{array}{r}-3 \\
\mathrm{~N}\end{array}$ & $\begin{array}{r}-2 \\
\mathrm{~N}\end{array}$ & $\begin{array}{r}-1 \\
N\end{array}$ & $\begin{array}{l}0 \\
G\end{array}$ & $\begin{array}{l}0 \\
\mathrm{~A}\end{array}$ & $\begin{array}{r}+1 \\
\mathrm{~N}\end{array}$ & $\begin{array}{r}+2 \\
\mathrm{~N}\end{array}$ & $\begin{array}{r}+3 \\
\mathrm{~N}\end{array}$ & $\begin{array}{r}+4 \\
N\end{array}$ \\
\hline $\mathrm{GABP} \alpha$ & $\begin{array}{l}\mathrm{G} \\
\mathrm{A}\end{array}$ & $\begin{array}{l}\mathrm{C} \\
\mathrm{g}\end{array}$ & $\begin{array}{l}\mathrm{C} \\
\mathrm{a}\end{array}$ & G & G & A & $\begin{array}{c}A \\
t\end{array}$ & $\begin{array}{c}\mathrm{G} \\
\mathrm{a}\end{array}$ & $\begin{array}{l}\mathrm{T} \\
\mathrm{c}\end{array}$ & $\mathrm{N}$ \\
\hline ER81 & $\begin{array}{c}\mathrm{G} \\
\mathrm{a}\end{array}$ & $\begin{array}{l}\mathrm{G} \\
\mathrm{c}\end{array}$ & $\begin{array}{l}\mathrm{C} \\
\mathrm{a}\end{array}$ & G & G & A & $\begin{array}{l}\mathrm{A} \\
\mathrm{T}\end{array}$ & $\begin{array}{c}G \\
a\end{array}$ & $\begin{array}{l}\mathrm{T} \\
\mathrm{c}\end{array}$ & $\mathrm{N}$ \\
\hline ER71 & $\begin{array}{l}\mathrm{G} \\
\mathrm{C}\end{array}$ & $\begin{array}{l}\mathrm{C} \\
\mathrm{G}\end{array}$ & $\begin{array}{l}\mathrm{C} \\
\mathrm{a}\end{array}$ & $\mathrm{G}$ & G & A & $\begin{array}{l}\mathrm{T} \\
\mathrm{A}\end{array}$ & $\begin{array}{c}\mathrm{G} \\
\mathrm{a}\end{array}$ & $\begin{array}{l}\mathrm{T} \\
\mathrm{c}\end{array}$ & C \\
\hline Ets-1 & $\begin{array}{c}A \\
\mathrm{~g}\end{array}$ & C & $\begin{array}{l}C \\
a\end{array}$ & $\mathrm{G}$ & G & A & $\begin{array}{l}\mathrm{A} \\
\mathrm{T}\end{array}$ & $\begin{array}{l}\mathrm{G} \\
\mathbf{a}\end{array}$ & $\begin{array}{l}\mathrm{C} \\
\mathrm{T}\end{array}$ & $\mathrm{N}$ \\
\hline E74 & $\begin{array}{l}\mathrm{C} \\
\mathrm{T}\end{array}$ & $\mathrm{C}$ & $\begin{array}{l}\mathrm{C} \\
\mathrm{a}\end{array}$ & G & G & A & A & $\begin{array}{c}\mathrm{G} \\
\mathbf{a}\end{array}$ & $\mathrm{T}$ & $\mathbf{N}$ \\
\hline
\end{tabular}

GABP $\alpha-$, ER81-, and ER71-binding site selection was determined with an oligonucleotide population prepared with GA dinucleotide flanked by 4 random nucleotides on each side (see Fig. 4). Two uppercase letters at a position indicate approximately equal selection; a lowercase letter indicates a less-favored nucleotide. Also shown are the optimal sequences for Ets-1 (Nye et al. 1992; Woods et al. 1992) and E74 (Urness and Thummel 1990). 

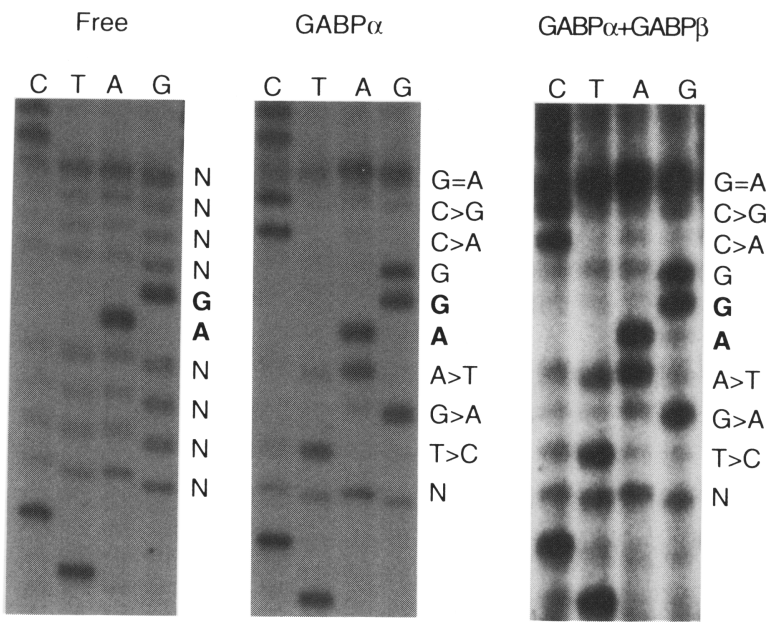

Figure 5. The nucleotide sequence of the binding site selected by GABP $\alpha$ in the presence and absence of GABP $\beta$. Autoradiog. raphy of DNA sequencing after three rounds of gel-shift and PCR amplification. The sequence of the starting oligonucloetide is shown in the left panel (Free). The selected nucleotides (complement of those determined by the sequencing) are desig. nated by the letters at right.

that it recognizes an as yet unidentified ets-related protein or possibly an unrelated protein. To test this possibility, we used radiolabeled GABP $\beta$ to probe total tissue extracts. Various mouse tissues were homogenized directly in boiling SDS/ $\beta$-mercaptoethanol containing buffer. Approximately equal amounts of protein, as judged by Coomassie blue staining (Fig. 7A), were subjected to SDS-PAGE and transferred to Immobilon membranes. Following denaturation and renaturation, the membrane was probed with ${ }^{32} \mathrm{P}$-labeled GABP $\beta$ (see Material and methods). Predominantly one protein band of $\sim 58 \mathrm{kD}$ was recognized by ${ }^{32} \mathrm{P}$-labeled GABP $\beta$ (Fig. $7 \mathrm{~B}$ ). This band was identified as GABP $\alpha$ by two criteria. First, it comigrated with Escherichia coli expressed GABP $\alpha$. Second, immunochemical staining with antibodies directed against GABPa detected this $58-\mathrm{kD}$ species in the same relative amounts that were detected by ${ }^{32} \mathrm{P}$-labeled GABP $\beta$ (Fig. 7C). These results indicated that GABP $\beta$ forms a very specific high-affinity complex with GABP $\alpha$. Even in tissues that express numerous ETS family members, such as thymus, GABP $\alpha$ was the only major protein species detected by ${ }^{32} \mathrm{P}$-labeled GABP $\beta$. Two caveats are that $\mathrm{GABP} \beta$ may target a protein that does not renature under these conditions or possibly a very rare protein below the limit of detection.

Residues within and immediately carboxy-terminal to the ETS domain of GABP $\alpha$ are required for high-affinity interaction with $G A B P \beta$

In earlier experiments it was demonstrated that GABP $\beta$ is capable of recognizing a truncated derivative of $\mathrm{GABP} \alpha$ containing the ETS domain and the remaining

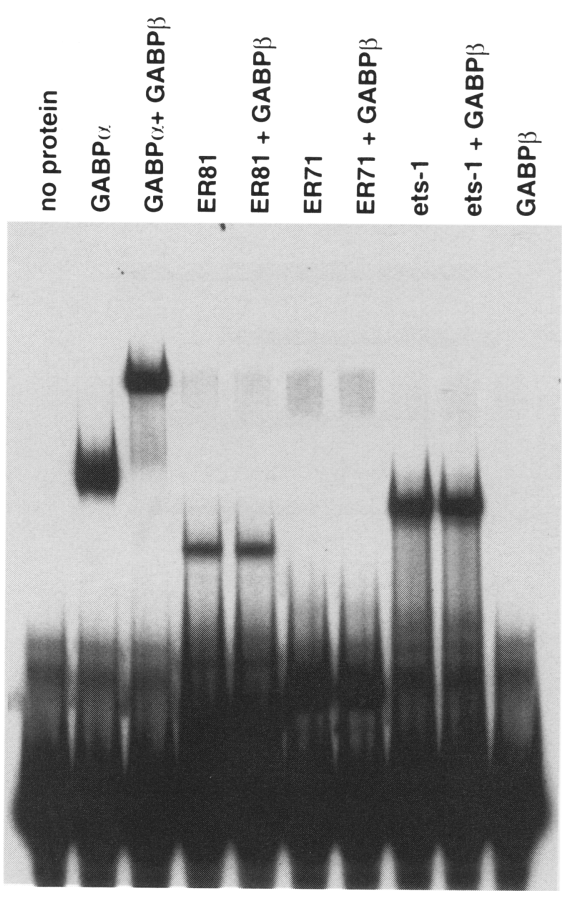

Figure 6. Gel-shift assay of DNA-binding of GABP $\alpha, E R 71$, ER81, and Ets-1 in the presence and absence of GABP $\beta$. E. coli expressed proteins were assayed for binding to an oligonucleotide containing a single ets-binding site. The proteins added to each binding reaction are indicated above each lane. The ER71shifted species is shown as the intense band that migrates near the free oligonucleotide.

carboxy-terminal residues (Thompson et al. 1991). A construct containing only the ETS domain, termed GABP $\alpha$ N313/C407 (Fig. 8), was able to bind DNA but could no longer interact with GABP $\beta$ (Thompson et al.
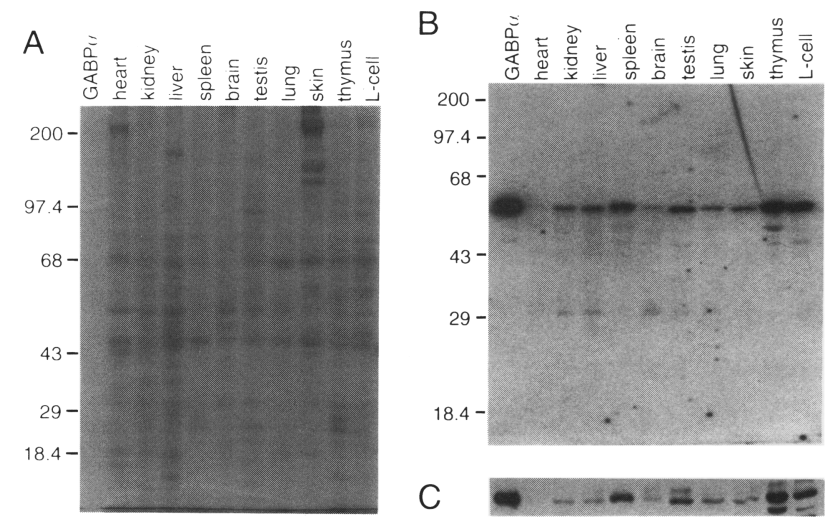

Figure 7. Protein interaction blotting of mouse tissue extracts with ${ }^{32} \mathrm{P}$-labeled GABP $\beta$. Various mouse tissues were homogenized in boiling SDS-sample buffer and subjected to SDS-PAGE. (A) Coommassie blue-stained gel; $(B)$ autoradiography of tissue extracts on Immobilon membranes probed with ${ }^{32} \mathrm{P}$-labeled $\mathrm{GABP} \beta ;(C)$ Western blot with rabbit anti-GABP $\alpha$ antibodies. 


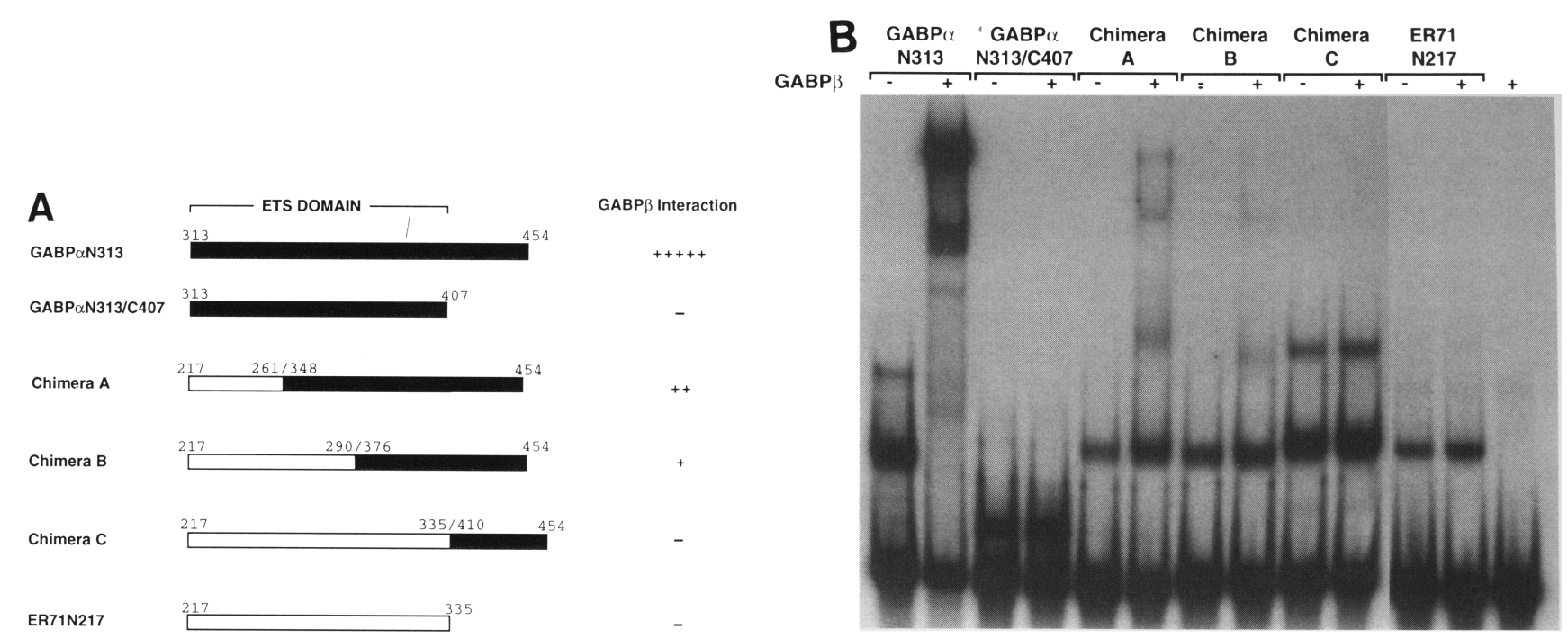

Figure 8. Gel-shift assay of GABP $\alpha$ and ER71 chimeric proteins. (A) Chimeric proteins were constructed as shown using PCR. Junctions were designed between two conserved amino acids with no added or deleted amino acids. $(B)$ Gel-shift assay of chimeric proteins in the presence and absence of GABP $\beta$. The oligonucleotide probe contained two ets-binding sites as found in the HSV-1 ICP4 gene.

1991). From these constructs, it was concluded that the region of $\mathrm{GABP} \alpha$ required for interaction with $\mathrm{GABP} \beta$ occurs within or near the conserved ETS domain. However, because truncations into the ETS domain of GABP $\alpha$ produced small proteins of limited solubility, it was not rigorously established as to whether the ETS domain of GABP $\alpha$ contributed to the interaction with GABP $\beta$. In addition, these ETS domain-deleted proteins lacked DNA-binding activity, thereby preventing detection of $\mathrm{GABP} \alpha / \mathrm{GABP} \beta$ interaction in a gel-shift assay.

To overcome the technical limitations in determining whether GABP $\beta$ recognizes determinants within the ETS domain of $G A B P \alpha$, we designed fusion proteins composed of ER71 and GABP $\alpha$. The chimeric proteins were engineered such that junctions occurred between 2 conserved residues and no extra amino acids were inserted (Fig. 8A). All constructs were expressed in E. coli and analyzed by gel-shift assay with an oligonucleotide containing two ets- binding sites as they occur in the HSV-1 ICP4 gene (Fig. 8B). All chimeric proteins bound to this oligonucleotide. Addition of GABP $\beta$ to the binding reaction quantitatively supershifted the DNA-bound GABP $\alpha \mathrm{N} 313$ but, as expected, did not affect ER71. Replacement of the amino-terminal approximately onethird of the ETS domain of GABP $\alpha$ with that of ER71 (chimera A) markedly decreased the ability of the chimera to complex with GABP $\beta$. Replacement of about two-thirds of the ETS domain of GABP $\alpha$ with that of ER71 (chimera B) further decreased the amount of GABP $\beta$ complex detected. Finally, addition of the carboxy-terminal region of $\mathrm{GABP} \alpha$ outside of the ETS domain to the end of the ER71-coding sequence /chimera C) afforded no detectable interaction with GABP $\beta$. Chimeric proteins $A, B$, and $C$ were also immobilized onto filters, denatured/renatured, and assayed for interaction with ${ }^{32} \mathrm{P}$-labeled GABP $\beta$ as described in the preceding section. Under these conditions, none of the chimeric proteins demonstrated detectable interaction with GABP $(T$. Brown, unpubl.). Therefore, both assays indicated that portions of the ETS domain of GABP $\alpha$ were important for interaction with GABP $\beta$.

In preparing chimeric proteins composed of two different ETS domains, we have made the assumption that the overall structural framework generated by this motif is similar. The ability of these chimeric proteins to specifically recognize an ets-binding site provides evidence that the protein can fold and bind DNA in a sequencespecific manner. The simplest interpretation of these studies is that sequences throughout the ETS domain and extending 37 amino acids toward the carboxyl terminus of $\mathrm{GABP} \alpha$ are required for interaction with GABP $\beta$. Despite sharing a similar structural framework with other ETS proteins, GABP $\alpha$ is somehow highly qualified for interaction with GABP $\beta$.

\section{Discussion}

In this report we have analyzed the DNA-binding and protein-protein interaction specificity of several ETS proteins. As part of this study, we report the molecular cloning and characterization of two new members of the ETS family, termed ER81 and ER71. Given their amino acid sequence similarity to other ETS family members and their capacity to bind DNA in a sequence-specific manner, we assume that ER71 and ER81 function as transcriptional regulatory proteins.

Certain ets-related genes are expressed with strict tissue specificity, whereas others are expressed in a wide variety of tissues. Ets-1 and Spi-1 are found only in hematopoietic cells (Bhat et al. 1987; Klemsz et al. 1990). 
Ets- 2 and Fli- 1 are expressed in a variety of tissues including thymus and spleen (Bhat et al. 1987; Ben-David et al. 1991); PEA3 is only found in brain, epididymis, and mammary glands (Xin et al. 1992); Elk-1 is limited to testes, lung, liver, and brain (Rao et al. 1989). ER71 represents a new example of the tissue-specific class of ETS proteins. In adult mice, ER71 mRNA was found only in testis. ER71 may regulate the transcription of genes important in testis specific processes such as spermatogenesis. For example, ER71 might represent the TIN-1 activity thought to repress $\mathrm{X}$ chromosomal genes during spermatogenesis (Goto et al. 1991).

ER81, like GABP $\alpha$, has a widespread tissue distribution. ER81 mRNAs were found in all tissues tested except liver. Previously, GABP $\alpha$ mRNA was found in all tissues tested (LaMarco et al. 1991). In this report, however, we were unable to detect GABP $\alpha$ mRNA in the brain. The complete absence of a hybridization signal indicates that this message is tightly regulated in the brain under some, as yet undetermined, physiological conditions. Such observations may be relevant to the pattern of infectivity of HSV-1. As we have shown, GABP binds to a cis-regulatory element important for HSV-1 IE gene activation (Triezenberg et al. 1988; LaMarco and McKnight 1989). Perhaps the absence of GABP $\alpha$ in the brain of adult mammals influences the growth cycle of HSV-1, favoring latency in neuronal cells over the lytic cycle common to other tissues and cell types.

Several recent reports indicate that different ETS family members have different DNA-binding specificities (Table 1). Two independent groups concur on the binding specificity of Ets-1: 5'-RCMGGAWRY-3' (Nye et al. 1992; Woods et al. 1992). As Nye et al. (1992) noted, the specificity of Ets-1 for residues in the minor groove differs slightly from that of E74: 5'-AAYCMGGAAGT-3' (Urness and Thummel 1990). The major difference is that E74 prefers a pyrimidine residue, 4 nucleotides 5 ' of the central GA pair, whereas Ets-1 prefers a purine at this position. Also, all of the oligonucleotides recognized by E74 had an A at position +1 , whereas selection by Ets-1 gave an A/T ratio of 1.4: 1 (Urness and Thummel 1990; Woods et al. 1992). It was suggested that differences in the flanking sequences in the recognition site mediate the specificity of the binding of different ETS proteins (Nye et al. 1992). In this study we have compared the binding site specificities of GABP $\alpha, E R 71$, and ER81. This analysis confirms that the ETS domain is capable of highly specific interactions with DNA and can discriminate between sequence variations spanning at least 10 nucleotides. Also, slight differences in binding site specificity exist between these ETS family members (Table 1). In some instances, the DNA-binding specificity detected in vitro may account for specificity of promoter action in vivo. For example, two ets-type DNA-binding sites in the interleukin-2 enhancer are binding sites for elf-1 but are not recognized by either ets-1 or ets-2 (Thompson et al. 1992). However, there are numerous members of the ETS family, and this motif recognizes a core DNA sequence that is nearly identical. Most striking, in our opinion, is the similarity of the optimal bind- ing sites of GABP $\alpha, E R 81, E R 71$, and Ets-1. It seems likely that discrimination of different promoter elements by the ETS family members will be governed by more compelling forces than these subtle differences in DNA-binding specificity alone. We believe that proteinprotein interactions, such as those we have characterized in the $\mathrm{GABP} \alpha / \mathrm{GABP} \beta$ complex, could provide the selectivity necessary for the discrimination of different promoters by different members of the ets family.

We have demonstrated, by gel-shift assay with known ETS proteins and by blotting of total tissue extracts, that GABP $\beta$ specifically recognizes only GABP $\alpha$. We predict that specific protein-protein interactions, such as those between $\mathrm{GABP} \alpha$ and GABP $\beta$, facilitate target selection by ETS family members. Target site recognition would be directed by the assembly ETS proteins with interacting factors, much like a jigsaw puzzle (Johnson and McKnight 1989; Thompson and McKnight 1992). For example, as diagramed in Figure 9, the ability of GABP $\beta$ to homodimerize brings two molecules of GABP $\alpha$ together in an $\alpha_{2} \beta_{2}$ tetramer. Tetramer formation drives GABP to bind with high affinity to the two tandem ets DNAbinding sites of the HSV-1 IE gene promoter. Similarly, it has been demonstrated by Dalton and Treisman (1992) that protein-protein interactions between SAP-1 and the serum response factor $(\mathrm{SRF})$ are required for the activity of SAP- 1 adjacent to the serum response element (SRE) of the c-fos promoter (Fig. 9). Other examples include ets-1 action adjacent to jun/fos at the APl site of the stromelysin promoter (Wasylyk et al. 1990, 1991) and PU.1 interaction with a protein at the immunoglobin $\kappa 3^{\prime}$ enhancer (Pongubala et al. 1992). We conclude that an

A

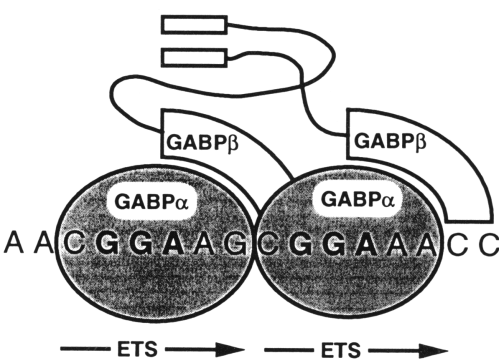

B

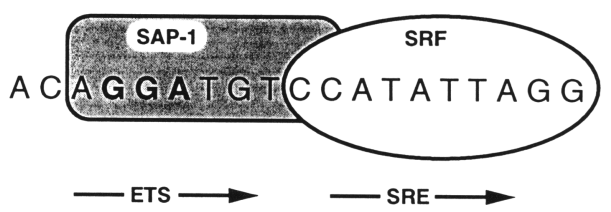

Figure 9. Protein-protein interactions contribute to the selection of DNA-binding sites by ETS proteins. (A) GABP $\alpha$ binds only weakly to the promoters of HSV-1 IE genes. The presence of GABP $\beta$ promotes the association of GABP $\alpha$ into an $\alpha_{2} \beta_{2}$ tetramer, resulting in high-affinity binding to two tandem GA-rich ets sites (Thompson et al. 1991). (B) SAP-1 requires proteinprotein interaction with SRF to act adjacent to SREs important in the induction of c-fos transcription (Dalton and Treisman 1992). 
important mechanism for providing specificity of ETS proteins is specific protein-protein interactions occurring at promoters. Protein-protein interactions direct GABP to preferentially act at promoters containing multiple ets sites, Ets-1 to act at sites adjacent to an AP-1 site, and SAP-1 to act adjacent to a SRE.

\section{Material and methods}

\section{cDNA cloning of ER71 and ER81}

The following four degenerate oligonucleotide probes were designed to hybridize to the conserved regions of the ETS domain: 5'-ATCCAGCTITGGCAGTTCCTICTIGAGCTICT-3'; 5'-ATCTCITGGA / GT / CIGGIGACGGA / GIGIGAGTTCAAGCT-3'; 5'-ATGAACTATGAGAAGCTITCICGIGG / CICTICGITATTTTA-3'; and 5'-GTIGCICA/GIIITTGGGGIA/CAGCGIAAGAACAA-3'. These oligonucleotides were used to screen an 8.5day mouse embryo library (S.-J. Lee 1990).

\section{E. coli expression}

Full-length GABP $\alpha, G A B P \alpha N 313, G A B P \alpha N 313 / C 407$, and fulllength $G A B P \beta$ were expressed in $E$. coli and purified as described previously (Thompson et al. 1991). E. coli expression vectors of chimeric proteins were constructed by PCR such that chimera A contained amino acids 207-261 of ER71 fused to amino acids $348-454$ of $\mathrm{GABP} \alpha$; chimera B contained amino acids 207-290 of ER71 fused to amino acids 376-454 of GABP $\alpha$; and chimera $C$ contained amino acids $207-335$ of ER71 fused to amino acids $410-454$ of GABP $\alpha$. For chimera A, PCR primers were designed to produce an amplified DNA fragment coding for amino acids 207-261 of ER71 with a 5' BamHI site and a $3^{\prime}$ EcoRI site, and PCR primers were used to produce an amplified DNA fragment coding for amino acids $348-454$ of GABP $\alpha$ with a $5^{\prime}$ EcoRI site and a $3^{\prime}$ HindIII site. These two fragment were ligated in a three-fragment ligation with $\mathrm{BamHI} / \mathrm{HindIII-cut} E$. coli expression vector pT5 (Thompson et al. 1991). The EcoRI site regenerated the Glu-Phe residues that are conserved between GABP $\alpha$ and ER71. Chimera B was constructed by similar methods except that the junction was an $\mathrm{XbaI}$ site between conserved Ser-Arg residues. In chimera $C$, the junction was constructed by the addition of an EcoRI site. In this case, the cloning led to the addition of a Glu-Phe dipeptide at the junction.

The ETS domains of ER71 (amino acids 208-335), ER81 (amino acids 333-477), Ets-1 (amino acids 170-440, as defined in Nye et al. 1992) and full-length GABP $\beta$ were cloned by PCR into the $E$. coli expression vector $\operatorname{pAR}(\Delta \mathrm{R} 1)$ that has been described by Blanar and Rutter (1992). This vector produced proteins that were tagged with an antibody recognition site (FLAG) and a substrate site for heart muscle protein kinase (HMK). The expressed proteins were isolated and partially purifed by chromatography on a mono-Q FPLC column (Pharmacia).

\section{Gel-shift assay}

DNA-binding reactions were done with $E$. coli-expressed proteins and the indicated ${ }^{32} \mathrm{P}$-labeled DNA probe in $25 \mathrm{~mm}$ Tris$\mathrm{HCl}(\mathrm{pH} 8.0), 3.0 \mathrm{mM} \mathrm{MgCl}, 0.5 \mathrm{~mm}$ EDTA, $50 \mathrm{~mm} \mathrm{KCl}, 2 \mathrm{~mm}$ DTT, $10 \%$ glycerol, and $50 \mu \mathrm{g} / \mathrm{ml}$ of bovine serum albumin with $1 \mu \mathrm{g}$ of poly[d(I-C)] per $20 \mu \mathrm{l}$ reaction. Reactions were incubated at $4^{\circ} \mathrm{C}$ for $30 \mathrm{~min}$ and subjected to electrophoresis on $5 \%$ polyacrylamide gels in recirculating $0.25 \times$ TBE at $4^{\circ} \mathrm{C}$. The double-stranded oligonucleotide containing two ets-binding sites was created by annealing $5^{\prime}$-AGCTTGCGGAACGGAAGCGGAAACCGCCGGATCG-3' and 5'-GATCCGATCCGGCGGTTTCCGCTTCCGTTCCGC-3'. The double-stranded oligonucleotide containing a single $e t s$-binding site was created by annealing 5'-AACCAAGCTTGAGTACCGGAAGAGTACACCG-3' and 5'-AACCAAGCTTCGGTGTACTCTTCCGGTACTC-3'.

\section{Probing with $G A B P \beta$}

Various mouse tissues were homogenized in boiling $0.625 \mathrm{M}$ Tris-HCl (pH 6.8), 2\% SDS, 5\% $\beta$-mercaptoethanol using a Poltron homogenizer (Brinkmann). Approximately equal amounts of protein were subjected to SDS-PAGE and electrophoretically transferred to Immobilon membranes (Millipore). Filters were denatured and renatured as described (Vinson et al. 1988). Filters were then treated for $60 \mathrm{~min}$ in blocking buffer $20 \mathrm{mM}$ HEPES$\mathrm{KOH}$ (pH 7.7), $5 \%$ Carnation nonfat dry milk, $0.05 \%$ Tween 20 , $1 \mathrm{mM} \mathrm{DTT}$ ], followed by $30 \mathrm{~min}$ in HYB buffer $20 \mathrm{~mm}$ HEPES$\mathrm{KOH}(\mathrm{pH} 7.7), 75 \mathrm{mM} \mathrm{KCl}, 1 \%$ Carnation nonfat dry milk, 2.5 $\mathrm{mm} \mathrm{MgCl}_{2}, 0.1 \mathrm{~mm}$ EDTA, $0.05 \%$ Tween 20, $1 \mathrm{~mm}$ DTT]. HMK-GABP $\beta$ was radiolabeled with $\left[\gamma^{-32} \mathrm{P}\right] \mathrm{ATP}$ using HMK (Sigma) and hybridized at $4^{\circ} \mathrm{C}$ for $4 \mathrm{hr}(250,000 \mathrm{cpm} / \mathrm{ml}$ in HYB buffer $\mid$. After hybridization, the filter was washed three times at $4^{\circ} \mathrm{C}$ with HYB buffer for $10 \mathrm{~min}$ each time and exposed to X-ray film.

\section{Binding site selection}

Binding site selection (SAAB) was performed essentially as described by Blackwell and Weintraub (1990), with the following exceptions. The sequences of the oligonucleotides were as follows: Template, 5'-AGACCGTACCATTGCAACCCCCNNNNGANNNNCTGATCTGTAGCAATTCGGA-3'; primer A, 5'-TCCGAATTGCTACAG-3'; and primer B, 5'-AGACCGTACCATTGCA-3'. Binding reactions were done with $E$. coliexpressed proteins under the conditions described above. After three rounds of selection and amplification, the final oligonucleotide population was sequenced using primer $\mathrm{A}$.

\section{Northern blotting}

Poly $(\mathrm{A})^{+}$RNA was isolated from 18-month-old mice (CD-1, Charles River Laboratoryl by standard methods. Ten micrograms of once-selected poly $(A)^{+}$RNA was subjected to electrophoresis through denaturing formaldehyde-agarose gels, transferred to GeneScreen membranes (New England Nuclear), and probed with randomly primed ${ }^{32} \mathrm{P}$-labeled DNA probes corresponding to ER71, ER81, and GABP $\alpha$. Between successive probes the filter was stripped by boiling in water for $20 \mathrm{~min}$. Molecular mass estimates were obtained by comparison with RNA standards (BRL).

\section{Acknowledgments}

We thank the following people for generously providing critical reagents: Se-Jin Lee for the 8.5-day mouse embryo cDNA library; Barbara Graves for the ets-1 cDNA clone; and Mike Blanar for the pAR vector and protocols for its use. We also thank Bob Kingsbury and Elizabeth Ryan for technical support, Catherine Thompson for helpful discussions and important reagents, 
and Bill Kubiac for computer graphics assistance. T.A.B. was supported by a National Research Service Award fellowship awarded by the National Institutes of Health.

The publication costs of this article were defrayed in part by payment of page charges. This article must therefore be hereby marked "advertisement" in accordance with 18 USC section 1734 solely to indicate this fact.

\section{Note added in proof}

The nucleotide sequences of ER81 and ER71 have been submitted to the GenBank data library.

\section{References}

Ben-David, Y., E.B. Giddens, K. Letwin, and A. Bernstein. 1991. Erythroleukemia induction by Friend murine leukemia virus: Insertional activation of a new member of the ets gene family, Fli-1, closely linked to c-ets-1. Genes \& Dev. 5: 908 918.

Bhat, N.K., R.J. Fisher, S. Fujiwara, R. Ascione, and T.S. Papas. 1987. Temporal and tissue specific expression of mouse ets genes. Proc. Natl. Acad. Sci. 84: 3161-3165.

Blackwell, T.K. and H. Weintraub. 1990. Differences and similarities in DNA-binding preferences of $\mathrm{MyoD}$ and E2A protein complexes revealed by binding site selection. Science 250: $1104-1110$.

Blanar, M.A. and W.J. Rutter. 1992. Interaction cloning: Identification of a helix-loop-helix zipper protein that interacts with c-Fos. Science 256: 1014-1018.

Burtis, K.C., C.S. Thummel, C.W. Jones, F.D. Karim, and D.S. Hogness. 1990. The Drosophila 74EF early puff contains E74, a complex ecdysone-inducible gene that encodes two etsrelated proteins. Cell 61: 85-99.

Chen, T., M. Bunting, F.D. Karim, and C.S. Thummel. 1992. Isolation and characterization of five Drosophila genes that encode an ets-related DNA-binding domain. Dev. Biol. 151: 176-191.

Dalton, S. and R. Treisman. 1992. Characterization of SAP-1, a protein recruited by serum response factor to the c-fos serum response element. Cell 68: 597-612.

Goebl, M.G. 1990. The PU.1 transcription factor is the product of the putative oncogene Spi-1. Cell 61: 1161-1166.

Goto, M., T. Tamura, K. Mikoshiba, Y. Masamune, and Y. Nakanishi. 1991. Transcription inhibition of the somatic-type phosphoglycerate kinase gene in vitro by a testis-specific factor that recognizes a sequence similar to the binding site for Ets oncoproteins. Nucleic Acids Res. 19: 3959-3963.

Gunther, C.V., J.A. Nye, R.S. Bryner, and B.J. Graves. 1990. Sequence-specific DNA-binding of the proto-oncogene ets-1 defines a transcriptional activator sequence within the long terminal repeat of Moloney murine sarcoma virus. Genes \& Dev. 4: 667-679.

Johnson, P.F. and S.L. McKnight. 1989. Eukaryotic transcriptional regulatory proteins. Annu. Rev. Biochem. 58: 799839.

Karim, F.D., L.D. Urness, C.S. Thummel, M.J. Klemsz, S.R. KcKercher, A. Celada, C. Van Beverean, R.A. Maki, C.V. Gunther, J.A. Nye, and B.J. Graves. 1990. The ets-domain: A new DNA-binding motif that recognizes a purine-rich core DNA sequence. Genes \& Dev. 4: 1451-1453.

Klemsz, M.J., S.R. McKercher, A. Celada, C. Van Beverean, and R.A. Maki. 1990. The macrophage and B cell specific transcription factor PU.1 is related to the ets oncogene. Cell 61: 113-124.
LaMarco, K.L. and S.L. McKnight. 1989. Purification of a set of cellular polypeptides that bind to the purine-rich cis-regulatory element of herpes simplex virus immediate early genes. Genes \& Dev. 3: 1372-1383.

LaMarco, K., C.C. Thompson, B.P. Byers, E.M. Walton, and S.L. McKnight. 1991. Identification of ets- and Notch-related subunits in GA binding protein. Science 253: 789-792.

Lee, S.-J. 1990. Identification of a novel member (GDF-1) of the transforming growth factor- $\beta$ superfamily. Mol. Endocrinol. 4: $1034-1040$.

LePrince, D., A. Gegonne, J. Coll, C. de Taisne, A. Schneeberger, C. Lagrou, and D. Stehelin. 1983. A putative second cellderived oncogene of the avian leukemia retrovinus E26. $\mathrm{Na}$ ture 306: 395-397.

Michaely, P. and V. Bennett. 1992. The ANK repeat: A ubiquitous motif involved in macromolecular recognition. Trends Cell Biol. 2: 127-129.

Moreau-Gachelin, F., A. Tavitian, and P. Tambourin. 1988. Spi-1 is a putative oncogene in virally induced murine erythroleukemias. Nature 331: 277-280.

Nunn, M.F., P.H. Seeburg, C. Moscovici, and P.H. Duesberg. 1983. Tripartite structure of the avian erythroblastosis virus E26 transforming gene. Nature 306: 391-395.

Nye, J.A., J.M. Petersen, C.V. Gunther, M.D. Jonsen, and B.J. Graves. 1992. Interaction of murine Ets-1 with GGA-binding sites establishes the ETS domain as a new DNA-binding motif. Genes \& Dev. 6: 975-990.

Pongubala, J.M.R., S. Nagulapalli, M.J. Klemsz, S.R. McKercher, R.A. Maki, and M.L. Atchison. 1992. PU.1 recruits a second nuclear factor to a site important for immunoglobulin $\times 3^{\prime}$ enhancer activity. Mol. Cell. Biol. 12: 368-378.

Pribyl, L.J., D.K. Watson, R.A. Schulz, and T.S. Papas. 1991. D-elg, a member of the Drosophila ets gene family: A sequence, expression and evolutionary comparison. Oncogene 6: $1175-1183$.

Rao, V.N., K. Huebner, M. Isobe, A. Ar-Rushdi, C.M. Croce, and E.S.P. Reddy. 1989. elk, Tissue-specific ets-related genes on chromosomes $\mathrm{X}$ and 14 near translocation breakpoints. Science 244: 66-70.

Reddy, E.S.P., V.N. Rao, and T.S. Papas. 1987. The erg gene: A human gene related to the ets oncogene. Proc. Natl. Acad. Sci. 84: 6131-6135.

Thompson, C.B., C.-Y. Wang, I.-C. Ho, P.R. Bohjanen, B. Petryniak, C.H. June, S. Miesfeldt, L. Zhang, G.J. Nabel, B. Karpinski, and J.M. Leiden. 1992. cis-Acting sequences required for inducible interleukin-2 enhancer function bind a novel etsrelated protein, elf-1. Mol. Cell. Biol. 12: 1043-1053.

Thompson, C.C. and S.L. McKnight. 1992. Anatomy of an enhancer. Trends Genet. 8: 232-236.

Thompson, C.C., T.A. Brown, and S.L. McKnight. 1991. Convergence of ets-and notch-related structural motifs in a heteromeric DNA-binding complex. Science 253: 762-768.

Triezenberg, S.J., K.L. LaMarco, and S.L. McKnight. 1988. Evidence of DNA : protein interactions that mediate HSV-1 immediate early gene activation by VP16. Genes \& Dev. 2: $730-742$.

Urness, L.D. and C.S. Thummel. 1990. Molecular interactions within the ecdysone regulatory hierarchy: DNA-binding properties of the Drosophila ecdysone-inducible E74A protein. Cell 63: 47-61.

Vinson, C.R., K.L. LaMarco, P.F. Johnson, W.H. Landschulz, and S.L. McKnight. 1988. In situ detection of sequence-specific DNA-binding activity specified by a recombinant bacteriophage. Genes \& Dev. 2: 801-806.

Wasylyk, B., C. Wasylyk, P. Flores, A. Begue, D. Leprince, and D. Stehelin. 1990. The c-ets proto-oncogenes encode tran- 
Brown and McKnight

scription factors that cooperate with c-Fos and c-Jun for transcriptional activation. Nature 346: 191-193.

Wasylyk, C., A. Gutman, R. Nicholson, and B. Wasylyk. 1991. The c-Ets oncoprotein activates the stromolysin promoter through the same elements as several non-nuclear oncoproteins. EMBO I. 10: 1127-1134.

Watanabe, H., T. Wada, and H. Handa. 1990. Transcription factor E4TFl contains two subunits with different functions. EMBO I. 9: 841-847.

Watson, D.K., M.J. McWilliams, P. Lapis, J.A. Lautenberger, C.W. Schweinfest, and T.S. Papas. 1988. Mammalian ets-1 and ets- 2 genes encode highly conserved proteins. Proc. Natl. Acad. Sci. 85: 7862-7866.

Woods, D.B., J. Ghysdael, and M.J. Owen. 1992. Identification of nucleotide preferences in DNA sequences recognized specifically by c-Ets-1 protein. Nucleic Acids Res. 20: 699-704.

Xin, J.-H., A. Cowie, P. Lachance, and J.A. Hassell. 1992. Molecular cloning and characterization of PEA3, a new member of the Ets oncogene family that is differentially expressed in mouse embryonic cells. Genes \& Dev. 6: $481-496$. 


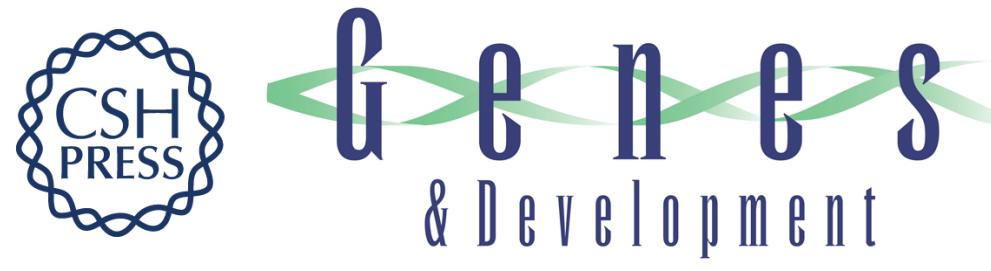

\section{Specificities of protein-protein and protein-DNA interaction of GABP alpha and two newly defined ets-related proteins.}

T A Brown and S L McKnight

Genes Dev. 1992, 6:

Access the most recent version at doi:10.1101/gad.6.12b.2502

References This article cites 37 articles, 18 of which can be accessed free at:

http://genesdev.cshlp.org/content/6/12b/2502.full.html\#ref-list-1

License

Email Alerting

Service

Receive free email alerts when new articles cite this article - sign up in the box at the top right corner of the article or click here.

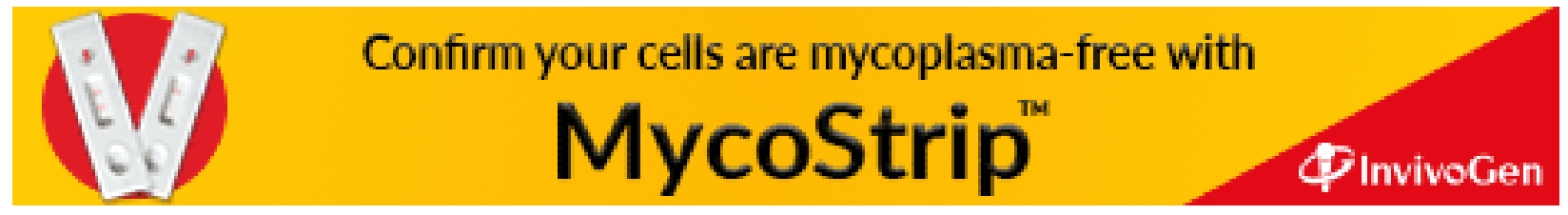

